Mauritius in 1945 indicated that the disease was endemic, there being malnutrition, overcrowding and increased prevalence of intestinal disease throughout the island at the time. The Committee has also recommended that it should accept the responsibility for taking over and staffing in two years time the research laboratories which the Rockefeller Foundation has established at Entebbe, Uganda, and Lagos, Nigeria.

The first annual report of the Committee for Colonial Agricultural, Animal Health and Forestry Research, established in June 1945, gives the detailed terms of reference of the Committee, which are determined so as to delineate clearly the functions as between the Committee and the Colonial Advisory Council for Agriculture, Animal Health and Forestry. Full co-operation is secured by overlapping membership and close contact between the secretariats of the two bodies. The Committee met seven times during the period and has set up a sub-committee on policy to facilitate consideration of basic policy. The most important matters before the Committee were the re-organisation and expansion of regional agricultural research in East Africa, and the organisation of oil palm research in West Africa; both raised the question of the distribution of research effort between basic and general problems of given regions and problems of particular erops of actual or potential economic importance. Generally, the Committee inclines to the view that the basic and general approach is the one which will be most fruitful in the long run, and it has also reached the provisional conclusion that institutions are required which can devote themselves without interruption to the study of long-term problems. Questions of personnel and terms of service as well as of the control of scientific work have also engaged the attention of the Committee, which hopes to present in its next annual report a clear statement of the general lines of policy which it is intended to follow.

\section{REPORTS OF THE ATOMIC ENERGY COMMISSION}

$\mathrm{T}$ HE first report of the Atomic Energy Commission to the Security Council of the United Nations, dated December 31, 1946, includes first reports also on scientific and technical aspects of the problem of control and on the safeguards required to ensure the use of atomic energy only for peaceful purposes*. The Commission records its approval of the former report from the Scientific and Technical Committee and incorporates in its findings the conclusions of that Committee. A summary is given of the second report, also approved by the Commission, which has reached the further general finding that scientifically, technologically and practically, it is feasible to extend among all nations the exchange of basic scientific information on atomic energy for peaceful ends, to control atomic energy to the extent necessary to ensure its use only for peaceful purposes, to eliminate atomic weapons from national armaments and to provide effective safeguards by way of inspection and other means to protect complying States against the hazards of violations and evasions. Effective control of atomic energy depends at present upon effective control of the production and use of uranium, thorium and their fissionable derivatives.

* See Department of State Bulletin, 16, 105 (No. 394, Jan. 19, 1947).
The development and use of atomic energy are not regarded as essentially matters of domestic concern of the individual nations, but rather have predominantly international implications and repercussions. An effective system of control must be international and established by an enforceable multilateral treaty or convention administered and operated by an international organ or operation within the United Nations, possessing adequate powers, and properly organised, staffed and equipped for the purpose. International agreement to outlaw the national production, possession, and use of atomic energy is an essential part of any such international system of control and inspection, although standing alone such agreement would be ineffective.

In accordance with these findings, the Commission recommends the establishment of a strong and com. prehensive international system of control and inspection, the scope and functions of which should be defined by a treaty or convention, and which should become operative only when those members of the United Nations necessary to assure its success have bound themselves to accept and support it by signing and ratifying the treaty or convention. It is recommended also that the treaty shall include a clause to the effect that the rule of unanimity of the permanent members of the Security Council shall not relate to the work of the control agency, and that no Government shall possess any right of veto over the fulfilment by the agency of any of its obligations under the treaty. In addition to promoting the exchange of basic scientific information on atomic energy for peaceful ends and its responsibility for preventing the use of atomic energy for destructive purposes, the agency should have responsibilities for research and development in order to remain in the forefront of atomic knowledge. The exclusive right to carry on atomic research for destructive purposes should be vested in the agency, which should also establish appropriate safeguards for research in nuclear physics having a direct bearing on the use of atomic energy. Such safeguards should not interfere with the prosecution of scientific research, or the publication of its results, provided no dangerous use or purpose is involved. The treaty or convention should embrace the entire programme for putting the international system of control and inspection into effect and should provide a schedule for the com. pletion of the transitional process over a period of time, step by step, in an orderly and agreed sequence leading to the full and effective establishment of international control.

At its meeting on March 10, the Security Council referred back to the Commission this first report with a request to prepare a draft treaty or convention, incorporating its ultimate proposals, and to submit a second report before the next session of the General Assembly. Mr. A. A. Gromyko's statement of the U.S.S.R.'s position, on March 5, ignored the Commission's finding that prohibition of atomic weapons would be ineffective except as part of a system of international inspection. He rejected the whole idea of inspection and of infringements of national sovereignty, and distorted the conception of the international control agency developed in the report, as well as the comments of the Council of the Atomic Scientists' Association on the American and Russian proposals before the Commission (spe Nature, 159, 47 ; 1947) without advancing any constructive proposals to meet the difficulties he stressed. At the Security Council's meeting on March 10, Mr. W. R. 
Austin vigorously refuted the allegation that the United States sought either a monopoly or to impose its will on other countries in questions of atomic energy. Referring to the Declaration of November 15, 1945, by the President of the United States and the Prime Ministers of the United Kingdom and of Canada, Mr. Austin said that the United States Government had made it clear that it welcomed all constructive suggestions which might advance the solution of the common problem and fulfil the mandate of the General Assembly resolution. Strong support for the United States position was forthcoming from the French delegation, and those of China and Australia.

\section{HORMONES AND FRUIT-FALL}

$\mathrm{T}$ HE year 1939 marked the publication by $\mathrm{F}$. E. Gardner, P. C. Marth and L. P. Batjer of their important discovery that the spraying of synthetic growth-substances on young apples prevented the natural shedding of fruit, which often reduced the crop quite substantially. These findings have been confirmed and expanded by many workers, and Dr. M. C. Vyvyan, of East Malling, has summarized the large amount of research which has been done on the subject*.

Fruit-drop has several causes. It may arise from structural defects, from non-pollination, from various types of non-fertilization, and from the abortion of embryos ; nutritional conditions also seem important. One section of the bulletin considers the proportion of blossom which will become mature fruit, and another part records some of the variations in fruitfall according to variety. The mechanism of abscission may, or may not, involve cell division, and these differing types of fruit-fall may be related to variations in response to growth substances. Certain naphthalene derivatives, for example, exert a marked effect on pre-harvest drop of many apple varieties, but have little or no effect in preventing 'June drop'.

A careful and detailed tabulation of extensive results allows certain generalizations. For the control of fruit-drop with most varieties, "nothing better than naphthaleneacetic acid or the acetamide seems to be required". Evidence on the optimum concentration is rather conflicting, but in most cases it is probably best to use the 'standard' concentration of 10 p.p.m. Temperatures between spraying and picking seem to influence the duration rather than the intensity of spray effect. Rain may be harmful if it falls before the spray has had time to dry. Sprays vary in their duration of effect ; they are not, however, in general, effective until five or six days after application, and remain active for two or three weeks. 'The timing of treatment is therefore most important. Pure naphthaleneacetic acid and acetamide are sparingly soluble in water; they are accordingly dissolved in a little alcohol before dilution. The synthetic growth-substances may also be applied as dusts, though further work is necessary before such convenient applications can be recommended for general commercial use. Results reviewed by Dr. Vyvyan do not suggest that fruit retained on the tree by hormone sprays has markedly different storage characters from fruit ripened normally. Small varia. tions do, however, occur, and further work is desirable.

- Imp. Bur. Hort. and Plantation Crops, Tech. Comm. No. 18 obtainable from I.A.B. Sales Branch, Penglais, Aberystwyth (1946) 38. $6 d$. net.
This bulletin is an admirable summary of work on the control of fruit-fall. It provides new horticultural equipment for the fruit grower and should give direction and stimulation to further research on the subject. Fruit-fall is not, however, always an unmitigated evil, and while pre-harvest drop provides the clearest need for control by hormone sprays, the ultimate practical control of previous 'drops' may lie in an adjustment, earlier in the season, of the amount of blossom to nutritional potentialities of particular trees. This gentle warning provides no disparagement of the volume under review, for Dr. Vyvyan's text does not introduce synthetic growth-substances as a panacea for all troubles. They rather provide a welcome remedy for a specific difficulty.

JohN GraINGer

\section{BIOCHEMISTRY IN BELGIUM}

$\mathrm{T}$ HE relative scientific isolation of the enemy. occupied countries during the War has engendered a determined post-war effort on the part of research workers of such countries to use with the maximum efficiency opportunities to contact workers in other countries. The appearance of publications reviewing the work of the past seven years in as wide a manner as possible is one outcome of this determination.

A series of short monographs is now appearing under the general title "Actualités Biochimiques", published (Liège : Éditions Desoer; Paris: Masson et Cie.) under the editorship of Prof. Marcel Florkin, of the University of Liège. The first of these, written by Prof. Florkin himself in 1945, is entitled "Aperçus sur les Progrès de la Biochimie, dans les Pays Anglo-Saxons, Depuis 1940", and represents a bird'seye view obtained from visits in June 1945, made possible by Le Fonds National de la Recherche Scientifique de Belgique. This volume surveys work carried out in the United States of America as well as that in Great Britain, and covers an extremely wide field effectively, but in a manner which is necessarily somewhat superficial. The subject of British antilewisite (B.A.L.) is treated in a later volume (No. 8, published in 1947, entitled "Travaux Récents sur les Toxiques de Guerre"), by Prof. Z. M. Bacq, in which the well-known fascinating story is told with all due credit to the genius of R. A. Peters.

It is unavoidable that the standard of the volumes of this series should vary, since the outlook of the authors is widely different. The second of the series, entitled "Données Récentes sur la Nature et le Métabolisme de L'Os", by Prof. Marcel J. Dallemagne (University of Liège), is an interesting exposition on bone metabolism in which the physical properties are discussed in relation to functional biochemical aspects, and which includes a useful section on hormones. No. 3, on "L'Évolution du Métabolisme des Substances Azotées chez les Animaux", by Prof. Florkin, is a very useful summary of work which is widely scattered and difficult to come by within the covers of one volume, and it is a tribute to biochemists in Belgium that such an insistent interest is shown in comparative aspects of the subject. No. 4 is the first of more than one volume dealing with new methods of clinical analyses, entitled "Méthodes Nouvelles D'Analyse Biochimique et Clinique", by Ghislaine Duchateau (University of Liège), a subject on which it appears that more information will be given later. No. 5 (Pierre Fredericq) discusses "Données Récentes sur la Coagulation du Sang", while No. 6 deals with 